\title{
Peningkatan Hasil Belajar PKn Materi Organisasi melalui Model Numbered Head Together di Kelas V
}

\author{
Endah Tri Wahyuni ${ }^{1}$ \\ ${ }^{1}$ Universitas Negeri Malang \\ Email: 1endahtriw7@gmail.com
}

\section{Tersedia Online di \\ http://www.jurnal.unublitar.ac.id/ index.php/briliant}

\begin{tabular}{l}
\hline Sejarah Artikel \\
\hline Diterima pada 5 November 2017 \\
Disetuji pada 5 November 2017 \\
Dipublikasikan pada 13 \\
November 2017 Hal. $494-503$ \\
\hline
\end{tabular}

\section{Kata Kunci:}

hasil belajar, pkn, numbered head together,

\section{DOI:}

http://dx.doi.org/10.28926/briliant .v2i4.111

\begin{abstract}
Abstrak: Penelitian peningkatan hasil belajar pendidikan kewarganegaraan melalui model Numbered Heads Together bertujuan untuk mendeskripsikan penerapan model Numbered Heads Together dalam pendidikan kewarganegaraan dengan materi organisasi dan menggambarkan peningkatan hasil belajar siswa dengan menggunakan model Numbered Heads Together. Ini akan sangat berguna bagi siswa dan guru dalam belajar. Model Numbered Heads Together juga dapat meningkatkan aktivitas guru dan siswa. Penelitian ini merupakan penelitian tindakan kelas. Hasil penelitian menunjukkan (1) Penerapan model pembelajaran Numbered Heads Together pada pembelajaran PKn dilaksanakan guru dengan baik dan sesuai dengan langkah-langkah pembelajaran Numbered Heads Together, (2) siklus I, ketuntasan belajar klasikal mengalami peningkatan sebesar $67 \%$ dengan kualifikasi cukup dan pada siklus II ketuntasan klasikal meningkat menjadi $92 \%$ dengan kualifikasi sangat baik.
\end{abstract}

Dalam proses pembelajaran tidak bisa lepas dari tujuan yang akan dicapai dan hasil belajar yang diharapkan. Bukti bahwa seseorang telah belajar adalah terjadinya perubahan tingkah laku pada orang tersebut, misalnya dari tidak tahu menjadi tahu, dari tidak mengerti menjadi mengerti. Dalam hal ini, Sudjana (2009:3) mengemukakan hasil belajar siswa pada hakikatnya adalah perubahan tingkah laku sebagai hasil belajar dalam pengertian yang lebih luas mencakup bidang kognitif, afektif, dan psikomotorik. Hasil belajar merupakan salah satu bagian terpenting dalam pembelajaran. Hasil belajar siswa dapat dicapai atas adanya usaha untuk belajar dan merupakan suatu akibat dari proses belajar dengan menggunakan alat pengukuran dalam ranah kognitif, afektif dan psikomotorik dengan menempuh serangkaian evaluasi atau tes yang disusun secara terencana baik tes tertulis, tes lisan, maupun tes perbuatan yang hasilnya dapat dinyatakan dalam angka, simbol, maupun kalimat.

Dimyati dan Mudjiono (2006:3) juga menyebutkan hal yang sama bahwa hasil belajar merupakan hasil dari suatu interaksi tindak belajar dan tindak mengajar. Dari sisi guru, tindak mengajar diakhiri dengan proses evaluasi belajar. Dari sisi siswa, hasil belajar merupakan berakhirnya penggal dan puncak proses belajar. Hasil belajar merupakan puncak dari proses belajar. Hasil belajar tersebut terjadi berkat evaluasi guru. Hasil belajar diperoleh dari proses belajar siswa selama pembelajaran berlangsung, penilaian hasil tes akhir, dan Lembar Kerja Kelompok (LKK). Dari hasil belajar itu juga dapat digunakan untuk (1) menentukan nilai minimal, (2) penentu kenaikan kelas, (3) mendiagnosa 
permasalahan siswa dalam belajar, (4) mengetahui kemajuan belajar siswa, dan (5) memotivasi siswa.

Begitu pula dengan Pendidikan Kewarganegaraan (PKn) yang merupakan salah satu mata pelajaran yang wajib diberikan pada jenjang pendidikan sekolah termasuk sekolah dasar. Pendidikan Kewarganegaraan juga memerlukan hasil belajar yang harus dicapai oleh siswa. Menurut UUSDN 1989 (dalam Absari, 2016:15) pendidikan dasar bertujuan memberikan bekal kemampuan dasar kepada peserta didik untuk mengembangkan kehidupannya sebagai pribadi, anggota masyarakat, warga negara dan anggota umat manusia serta mempersiapkan peserta didik untuk mengikuti pendidikan menengah". Sedangkan Pendidikan Kewarganegaraan bertujuan agar siswa mampu menjadi warga negara yang baik yang tahu, mau, dan sadar akan hak dan kewajibannya sehingga dapat berdemokrasi, berpengetahuan, bermoral, serta berketerampilan. Dalam pembelajaran PKn, diperlukan hasil belajar yang menyeluruh meliputi kemampuan memahami konsep, keterampilan proses Pendidikan Kewarganegaraan, dan penghayatan serta pengamalan nilai-nilai Pancasila.

Adanya model Numbered Heads Together dapat dimanfaatkan sebagai bentuk upaya untuk meningkatkan hasil belajar siswa pada mata pelajaran PKn. Numbered Heads Together adalah model pembelajaran dimana setiap siswa diberi nomor kemudian dibuat suatu kelompok secara acarak dan guru memanggil nomor dari siswa tersebut (Komalasari, 2010: 62). Model Numbered Heads Together pertama kali dikembangkan oleh Spenser Kagen pada tahun 1992 untuk melibatkan lebih banyak siswa dalam menelaah materi yang tercakup dalam suatu pelajaran dan mengecek pemahaman mereka terhadap isi materi pelajaran tersebut. Struktur Kagen menghendaki agar para siswa bekerja saling bergantung pada kelompok-kelompok kecil secara kooperatif.

Model pembelajaran Numbered Heads Together termasuk ke dalam pembelajaran kooperatif, dimana siswa belajar dan bekerja dalam suatu kelompok yang bersifat heterogen. Pengelompokan secara heterogen ini merupakan ciri-ciri yang menonjol dari model pembelajaran kooperatif. Sebab kelompok heterogen bisa dibentuk dengan memperhatikan keanekaragaman gender, latar belakang agama, sosial-ekonomi, dan suku budaya, serta kemampuan akademisnya. Dalam pembentukan model pembelajaran Numbered Heads Together biasanya terdiri dari siswa dengan kemampuan akademis tinggi, sedang, dan rendah. Kelompok heterogen lebih disukai oleh guru dalam pembelajaran, sebab menurut Lie (2005:43) "kelompok heterogen memberikan kesempatan kepada siswa untuk saling mendukung; meningkatkan relasi dari interaksi antar ras, agama, etnik, dan gender; memudahkan pengelolaan kelas”. Sejalan dengan Komalasari (2010: 62) yang menyebutkan bahwa pemanfaatan belajar berkelompok kecil dalam pembelajaran yang memungkinkan siswa bekerja bersama untuk memaksimalkan belajar mereka dan anggota lainnya dalam kelompok.

Pembelajaran dengan model Numbered Heads Together atau penomoran berpikir bersama dirancang untuk mempengaruhi pola interaksi siswa dan sebagai alternatif terhadap struktur kelas tradisional (Trianto, 2007: 82). Dalam hal ini, menurut Lie (2005:59) "teknik kepala bernomor memberikan kesempatan kepada siswa untuk saling membagikan ide-ide dan mempertimbangkan jawaban yang paling tepat. Teknik ini juga mendorong siswa untuk meningkatkan semangat kerjasama siswa". Model pembelajaran Numbered Hedas Together merupakan 
model pembelajaran yang lebih mengedepankan kepada aktivitas siswa dalam mencari, mengolah, dan melaporkan informasi dari berbagai sumber yang akhirnya dipresentasikan di depan kelas (Rahayu, 2006). Model pembelajaran Numbered Heads Together ini secara tidak langsung melatih siswa untuk saling berbagi informasi, mendengarkan dengan cermat serta berbicara dengan penuh perhitungan, sehingga siswa lebih produktif dalam pembelajaran. Adapun kelemahan model pembelajaran Numbered Heads Together dimana disebutkan oleh Sanjaya (2008: 254) sebagai berikut. (1) dengan leluasanya pembelajaran, maka apabila keleluasaan tersebut tidak dimanfaatkan semaksimal mungkin, maka tujuan dari pembelajaran tidak akan tercapai, (2) penilaian kelompok dapat membutakan penilaian secara individu apabila guru tidak jeli dan benar-benar teliti dalam pelaksanaannya, dan (3) mengembangkan kesadaran berkelompok memerlukan waktu yang tidak singkat.

Numbered Heads Together merupakan model yang dapat digunakan untuk meningkatkan hasil belajar siswa terutama pada mata pelajaran PKn. Langkah-langkah model pembelajaran Numbered Heads Together menurut Trianto (2007: 82) ada empat fase yaitu fase 1 numbering, fase 2 questioning, fase 3 heads together, dan fase 4 amswering. Fase 1 penomoran (numbering) siswa dibagi beberapa kelompok secara heterogen yang beranggotakan 3-5 siswa. Setiap anggota kelompok dalam satu kelompok mendapat nomor yang berbeda 1-5. Fase 2 pengajuan pertanyaan (questioning) guru mengajukan sebuah pertanyaan kepada siswa. Pertanyaan tersebut bervariasi dari yang spesifik hingga yang bersifat umum dalam bentuk kalimat tanya maupun perintah. Fase 3 berpikir bersama (heads together) siswa menyatukan atau menyamakan pendapatnya terhadap jawaban pertanyaan tersebut dan saling meyakinkan bahwa anggota kelompoknya mengetahui jawaban tersebut. Fase 4 (answering) guru memanggil satu nomor tertentu, kemudian siswa dari kelompok dengan nomor yang sama mengangkat tangan dan menyampaikan hasil diskusi kelompoknya ke seluruh kelas. Kelompok lain memberikan tanggapan, menyanggah, atau bertanya terhadap hasil diskusi kelompok tersebut.

\section{METODE}

Kehadiran peneliti di lapangan adalah peneliti berperan sebagai pengamat dan pelaksana pembelajaran yang dibantu oleh mitra peneliti yaitu guru kelas yang bertindak sebagai pengamat. Dalam penelitian ini, peneliti berperan sebagai pengamat, pengumpul data, penganalisis data, penyusun laporan penelitian, dan pelapor hasil penelitian. Penelitian dilaksanakan di kelas V SDN Tulungrejo 02 desa Tulungrejo kecamatan Karangrejo kabupaten Tulungagung. Subjek dalam penelitian ini adalah siswa dan guru kelas V tahun pelajaran 2016/2017. Siswa kelas V berjumlah 12 siswa dengan rincian 5 siswa laki-laki dan 7 siswa perempuan. Penelitian ini dilakukan selama dua siklus tindakan.

Teknik pengumpulan data yang digunakan dalam penelitian adalah teknik observasi, tes, dan dokumentasi. Data yang diambil dalam penelitian ini adalah data proses pembelajaran yaitu data tentang pelaksanaan pembelajaran PKn dengan model Numbered Heads Together. Sumber data dalam pelaksanaan model pembelajaran Numbered Heads Together adalah guru dan siswa kelas V SDN Tulungrejo 02. Analisis data yang digunakan dalam penelitian ini adalah data kualitatif yang dilakukan setelah pelaksanaan tindkan pada setiap siklus. 
Sugiyono (2009:337) menjelaskan bahwa aktivitas dalam analisis data yaitu reduksi data, penyajian data, dan penarikan kesimpulan. Data yang telah terkumpul dianalisis secara statistik guna mengetahui tingkat keterlaksanaan tindakan baik secara individual maupun secara klasikal.

\section{HASIL}

Hasil observasi terhadap aktivitas guru dalam melaksanakan pembelajaran PKn dengan menggunakan model Numbered Heads Together pada siklus I dan II disajikan pada tabel 1 sebagai berikut.

Tabel 1 Hasil Aktivitas Guru dalam Pembelajaran PKn Menggunakan Model Numbered Heads Together

\begin{tabular}{|l|c|c|c|c|}
\hline \multirow{2}{*}{ Keterangan } & \multicolumn{2}{|c|}{ SIKLUS I } & \multicolumn{2}{c|}{ SIKLUS II } \\
\cline { 2 - 5 } & Pertemuan 1 & Pertemuan 2 & Pertemuan 1 & Pertemuan 2 \\
\hline Jumlah skor & 13 & 15 & 16 & 17 \\
\hline Persentase & $72 \%$ & $83 \%$ & $89 \%$ & $94 \%$ \\
\hline
\end{tabular}

Persentase nilai aktivitas guru dalam pembelajaran PKn dengan menggunakan model Numbered Heads Together pada siklus I pertemuan 1 adalah $72 \%$ dengan kualifikasi cukup dan mengalami peningkatan sebesar $11 \%$ pada pertemuan 2 menjadi 83\% dengan kualifikasi baik. Pada Siklus II pertemuan 1 nilai aktivitas guru semakin meningkat dengan persentase $89 \%$ dengan kualifikasi baik dan pada pertemuan 2 persentase aktivitas guru mencapai $94 \%$ dengan kualifikasi sangat baik.

Hasil observasi terhadap aktivitas siswa dalam pembelajaran PKn dengan menggunakan model Numbered Heads Together pada siklus I dan siklus II disajikan pada tabel 2.

Tabel 2 Hasil Aktivitas Siswa dalam Pembelajaran PKn Menggunakan Model Numbered Heads Together

\begin{tabular}{|l|c|c|c|c|}
\hline \multirow{2}{*}{ Keterangan } & \multicolumn{2}{|c|}{ SIKLUS I } & \multicolumn{2}{c|}{ SIKLUS II } \\
\cline { 2 - 5 } & Pertemuan 1 & Pertemuan 2 & Pertemuan 1 & Pertemuan 2 \\
\hline Jumlah skor & 105 & 112 & 116 & 135 \\
\hline Jumlah nilai & 876 & 932 & 966 & 1034 \\
\hline Persentase & $73 \%$ & $78 \%$ & $81 \%$ & $86 \%$ \\
\hline Kualfikasi & Cukup & Cukup & Baik & Baik \\
\hline
\end{tabular}

Persentase aktivitas siswa selama pembelajaran PKn dengan menggunakan model Numbered Heads Together pada siklus I pertemuan 1 adalah 73\% dengan kualifikasi cukup dan pertemuan 2 persentase aktivitas siswa meningkat menjadi $78 \%$ dengan kualifikasi cukup. Sedangkan pada siklus II pertemuan 1 persentase aktivias siswa adalah $81 \%$ dengan kualifikasi baik dan pada pertemuan 2 meningkat 5\% menjadi 86\% dengan kualifikasi baik.

Selain aktivitas siswa, model pembelajaran Numbered Heads Together memiliki penilaian yang mencakup 3 ranah, yaitu ranah sikap, ranah keterampilan, dan ranah pengetahuan. Pada ranah sikap dan keterampilan penilaian dijadikan satu menajdi penilaian proses dimana penilaian tersebut diperoleh siswa selama kegiatan pembelajaran berlangsung dengan menggunakan model Numbered Heads Together. Berikut adalah paparan nilai proses yang meliputi nilai sikap dan 
keterampilan selama siklus I dan siklus II yang disajikan pada tabel 3 dan tabel 4 sebagai berikut.

Tabel 3 Nilai Sikap dan Nilai Keterampilan Siswa pada Pembelajaran PKn dengan Menggunakan Model Numbered Heads Together Siklus I

\begin{tabular}{lcccccc}
\hline \multirow{3}{*}{ Keterangan } & \multicolumn{7}{c}{ Siklus I } \\
\cline { 2 - 7 } & NS & NK & NP & NS & NK & NP \\
\cline { 2 - 7 } Jumlah & 865 & 881 & 876 & 928 & 896 & 913 \\
\hline Persentase & $72 \%$ & $73 \%$ & $73 \%$ & $77 \%$ & $75 \%$ & $76 \%$ \\
\hline Kualifikasi & Cukup & Cukup & Cukup & Baik & Cukup & Baik \\
\hline
\end{tabular}

Keterangan: NS: Nilai Sikap, NK: Nilai Keterampilan, NP: Nilai Proses

Tabel 3 diketahui bahwa nilai proses siswa yang meliputi nilai sikap dan nilai pengetahuan. Pada siklus I pertemuan 1 persentase nilai proses yang dicapai adalah $73 \%$ dengan kualifikasi cukup dan pada pertemuan 2 persentase nilai proses meningkat menjadi $76 \%$ dengan kualifikasi baik.

Tabel 4 Nilai Sikap dan Nilai Keterampilan Siswa pada Pembelajaran PKn dengan Menggunakan Model Numbered Heads Together Siklus II

\begin{tabular}{lcccccc}
\hline \multirow{3}{*}{ Keteterangan } & \multicolumn{7}{c}{ Siklus II } \\
\cline { 2 - 7 } & NS & NK & NP & NS & NK & NP \\
\cline { 2 - 7 } Jumlah & 978 & 983 & 982 & 1017 & 1020 & 1020 \\
\hline Persentase & $82 \%$ & $82 \%$ & $82 \%$ & $85 \%$ & $85 \%$ & $85 \%$ \\
\hline Kualifikasi & Baik & Baik & Baik & Baik & Baik & Baik \\
\hline
\end{tabular}

Keterangan: NS: Nilai Sikap, NK: Nilai Keterampilan, NP: Nilai Pengetahuan

Persentase nilai proses yang diperoleh siswa pada siklus II pertemuan 1 adalah $82 \%$ dengan kualifikasi baik dan meningkat pada pertemuan 2 menjadi 85\% dengan kualifikasi baik. Berdasarkan persentase dan kualifikasi tersebut maka dapat dikatakan bahwa siswa telah berhasil meningkatkan nilai proses yang terdiri dari nilai sikap dan nilai keterampilan pada pembelajaran dengan menggunakan model Numbered Heads Together.

Nilai pengetahuan masuk pada nilai hasil yang diperoleh siswa selama pembelajaran PKn dengan menggunakan model Numbered Heads Together dipaparkan pada tabel 5 dan tabel 6 sebagai berikut.

Tabel 5 Nilai Pengetahuan Siswa pada Pembelajaran PKn dengan Menggunakan Model Numbered Heads Together Siklus I

\begin{tabular}{lcccccc}
\hline \multirow{2}{*}{ Keterangan } & \multicolumn{7}{c}{ Siklus I } \\
\cline { 2 - 7 } & N LKK & NE & NH & N LKK & NE & NH \\
\cline { 2 - 7 } Jumlah & 889 & 750 & 821 & 912 & 915 & 916 \\
\hline Rata-rata & 74 & 63 & 68 & 76 & 76 & 76 \\
\hline Persen-tase & $74 \%$ & $63 \%$ & $68 \%$ & $76 \%$ & $76 \%$ & $76 \%$ \\
\hline Kualifikasi & Cukup & Cukup & Cukup & Baik & Baik & Baik \\
\hline
\end{tabular}

Keterangan: N LKK: Nilai Lembar Kerja Kelompok, NE: Nilai Evaluasi, NH: Nilai Hasil 
Persentase nilai pengetahuan yang masuk pada nilai hasil pada siklus I pertemuan 1 adalah $68 \%$ dengan kualifikasi cukup. Pada pertemuan 2, terjadi peningkatan persentase nilai pengetahuan menjadi $76 \%$ dengan kualifikasi baik.

Tabel 6 Nilai Pengetahuan Siswa pada Pembelajaran PKn dengan Menggunakan Model Numbered Heads Together Siklus II

\begin{tabular}{lcccccc}
\hline \multirow{2}{*}{ Keterangan } & \multicolumn{7}{c}{ Siklus II } \\
\cline { 2 - 7 } & N LKK & NE & NH & N LKK & NE & NH \\
\cline { 2 - 7 } Jumlah & 954 & 965 & 962 & 1005 & 981 & 995 \\
\hline Rata-rata & 80 & 80 & 80 & 84 & 82 & 83 \\
\hline Persen-tase & $80 \%$ & $80 \%$ & $80 \%$ & $84 \%$ & $82 \%$ & $83 \%$ \\
\hline Kualifikasi & Baik & Baik & Baik & Baik & Baik & Baik \\
\hline
\end{tabular}

Keterangan: N LKK: Nilai Lembar Kerja Kelompok, NE: Nilai Evaluasi, NH: Nilai Hasil

Persentase nilai pengetahuan yang masuk pada nilai hasil siswa pada siklus II pertemuan 1 ada;ah 80\% dengan kualifikasi baik. Pada pertemuan 2 meningkat sebesar 3\% menjadi 83\% dengan kualifikasi baik.

Nilai akhir pembelajaran PKn dengan menggunakan model Numbered Heads Together menjadi tolak ukur peningkatan hasil belajar dan ketuntasan siswa. Berikut paparan nilai akhir siswa pada siklus I dan siklus II

Tabel 7 Nilai Akhir Siswa Siklus I

\begin{tabular}{|c|c|c|c|c|c|c|c|c|c|c|}
\hline \multirow{3}{*}{ Ket. } & \multicolumn{10}{|c|}{ SIKLUS I } \\
\hline & \multicolumn{3}{|c|}{ Pertemuan 1} & \multicolumn{2}{|c|}{$\bar{K}$} & \multicolumn{3}{|c|}{ Pertemuan 2} & \multicolumn{2}{|c|}{$\bar{K}$} \\
\hline & NP & NH & NA & $\mathbf{T}$ & TT & NP & NH & NA & $\mathbf{T}$ & TT \\
\hline Jumlah & 876 & 821 & 857 & 6 & 6 & 913 & 916 & 919 & 8 & 4 \\
\hline $\begin{array}{l}\text { Rata- } \\
\text { rata }\end{array}$ & & 68 & 71 & & & & 76 & 77 & & \\
\hline $\begin{array}{l}\text { Persen- } \\
\text { tase }\end{array}$ & $73 \%$ & $68 \%$ & $71 \%$ & $50 \%$ & $50 \%$ & $76 \%$ & $76 \%$ & $77 \%$ & $67 \%$ & $33 \%$ \\
\hline $\begin{array}{l}\text { Kualifi- } \\
\text { kasi }\end{array}$ & $\begin{array}{l}\mathrm{Cu}- \\
\text { kup }\end{array}$ & $\begin{array}{l}\mathrm{Cu}- \\
\text { kup }\end{array}$ & $\begin{array}{l}\mathrm{Cu}- \\
\text { kup }\end{array}$ & $\begin{array}{l}\mathrm{Ku}- \\
\text { rang } \\
\mathrm{Se}- \\
\text { kali }\end{array}$ & & Baik & Baik & Baik & $\begin{array}{l}\mathrm{Cu}- \\
\text { kup }\end{array}$ & \\
\hline
\end{tabular}

Keterangan: Ket.: Keterangan, K: Ketuntasan, NP: Nilai Proses, NH: Nilai Hasil, NA: Nilai Akhir, T: Tuntas, TT: Tidak Tuntas

Nilai akhir siswa pada siklus I pertemuan 1 di ketahui bahwa ketuntasan siswa mencapai 50\% dengan kualifikasi kurang sekali yang artinya sebanyak 8 siswa tuntas belajar. Pada pertemuan 2 sebanyak 8 siswa tuntas belajar dan 5 siswa dinyatakan tidak tuntas belajar dengan persentase ketuntasan sebesar $67 \%$ dengan kualifikasi cukup.

Tabel 8 Nilai Akhir Siswa Siklus II

\begin{tabular}{|c|c|c|c|c|c|c|c|c|c|c|}
\hline \multirow{3}{*}{ Ket. } & \multicolumn{10}{|c|}{ SIKLUS II } \\
\hline & \multicolumn{3}{|c|}{ Pertemuan 1} & \multicolumn{2}{|c|}{$\bar{K}$} & \multicolumn{3}{|c|}{ Pertemuan 2} & \multicolumn{2}{|c|}{$\bar{K}$} \\
\hline & NP & NH & NA & $\mathbf{T}$ & TT & NP & NH & NA & $\mathbf{T}$ & TT \\
\hline Jumlah & 982 & 962 & 975 & 10 & 2 & 1020 & 995 & 1012 & 11 & 1 \\
\hline $\begin{array}{l}\text { Rata- } \\
\text { rata }\end{array}$ & & 80 & 81 & & & & 83 & 84 & & \\
\hline
\end{tabular}

499 BRILIANT: Jurnal Riset dan Konseptual Volume 2 Nomor 4, November 2017 


\begin{tabular}{|c|c|c|c|c|c|c|c|c|c|c|}
\hline $\begin{array}{l}\text { Persen- } \\
\text { tase }\end{array}$ & $82 \%$ & $80 \%$ & $81 \%$ & $83 \%$ & $17 \%$ & $85 \%$ & $83 \%$ & $84 \%$ & $92 \%$ & $18 \%$ \\
\hline $\begin{array}{l}\text { Kualifi- } \\
\text { kasi }\end{array}$ & Baik & Baik & Baik & Baik & & Baik & Baik & Baik & $\begin{array}{c}\text { Sa- } \\
\text { ngat } \\
\text { Baik }\end{array}$ & \\
\hline
\end{tabular}

Keterangan: Ket.: Keterangan, K: Ketuntasan, NP: Nilai Proses, NH: Nilai Hasil, NA: Nilai Akhir, T: Tuntas, TT: Tidak Tuntas

Nilai akhir siswa pada tabel 8 siklus I pertemuan 1 di ketahui bahwa ketuntasan siswa mencapai $83 \%$ dengan kualifikasi baik yang artinya sebanyak 10 siswa tuntas belajar dan 2 siswa tidak tuntas belajar. Pada pertemuan 2 sebanyak 11 siswa tuntas belajar dan 1 siswa tidak tuntas belajar dengan persentase ketuntasan sebesar 92\% dengan kualifikasi sangat baik. Berdasarkan ketuntasan individual dan klasikal tersebut dapat dikatakan bahwa pembelajaran PKn dengan menggunakan model Numbered Heads Together pada siklus II tuntas.

\section{PEMBAHASAN}

\section{Penerapan Model Numbered Heads Together dalam Pembelajaran PKn di Kelas V}

Data hasil penelitian pada pelaksanaan pembelajaran PKn dengan menggunakan model Numbered Heads Together di siklus I, aktivitas guru berjalan dengan cukup baik, dan aktivitas siswa baik. Hal ini, dapat dilihat dari pencapaian aktivitas guru pada siklus I pertemuan 1 aktivitas guru mencapai $72 \%$ dengan kualifikasi cukup dan meningkat menjadi $83 \%$ dengan kualifikasi baik pada pertemuan 2. Sehingga rata-rata persentase pencapaian aktivitas guru pada siklus I sebesar $78 \%$ dengan kualifikasi baik. Sementara pencapaian aktivitas siswa di siklus I pada pertemuan 1 sebesar $73 \%$ dengan kualifikasi cukup, dan mengalami peningkatan pada pertemuan 2 menjadi $78 \%$ dengan kualifikasi cukup. Rata-rata persentase aktivitas siswa pada siklus I sebesar $76 \%$ dengan kualifikasi baik.

Permasalahan yang muncul pada pembelajaran di siklus I antara lain peneliti yang bertindak sebagai guru belum dapat mengelola kelas dengan baik, belum dapat mengatur waktu dengan baik. Dalam pembentukan kelompok masih ada kegaduhan, karena kebanyakan siswa tidak berkelompok dengan temannya. Siswa masih terlihat pasif dalam pembelajaran, dan masih belum berani menyampaikan pendapat pada saat presentasi, hal ini dikarenakan siswa belum terbiasa melakukan diskusi dan bekerja kelompok. Selain itu, pada saat mengerjakan kerja kelompok, banyak waktu yang terbuang karena siswa tidak mau mengerjakan sebab merasa tidak cocok dengan anggota kelompoknya. Upaya-upaya yang dapat dilakukan oleh guru pada siklus berikutnya untuk mengatasi permasalahan tersebut adalah guru membuat kesepakatan dengan siswa dalam mengerjakan LKK ataupun pada saat presentasi dan mengerjakan tes evaluasi. Hal ini sejalan dengan pernyataan Sardiman (dalam Absari, 2016:81) yang menyatakan "ketepatan dalam penggunaan waktu perlu mendapat perhatian serius dari setiap guru, sehingga tidak terjadi pembuangan waktu yang sia-sia atau kekurangan waktu". Pembentukan kelompok dalam model Numbered Heads Together merupakan upaya guru dalam mengkondisikan siswa agar dapat berinteraksi dengan siswa lain dalam satu kelompok. Pembentukan kelompok di setiap pertemuan baik pada siklus I maupun siklus II, selalu berbeda anggota 
kelompoknya, sehingga interaksi siswa dengan siswa yang lain dapat merata dan diharapkan terjadi proses pembelajaran yang interaktif. Selain itu, guru juga dapat memberikan penguatan positiif baik secara lisan berupa pujian maupun dengan tindakan seperti tepuk tangan atau mengacungkan ibu jari kepada siswa. Dengan demikian diharapkan agar siswa yang pasif, terpacu untuk aktif.

Keaktifan siswa dalam pembelajaran dengan menggunakan model Numbered Heads Together, juga berdampak pada nilai proses yang diperoleh siswa. Siswa yang semula pasif pada tahap pratindakan, mulai tampak aktif pada siklus I. Nilai proses yang terdiri dari nilai sikap dan nilai keterampilan sangat penting bagi siswa, karena setiap perbuatan siswa ada nilainya, sehingga segala hal yang dilakukan siswa dalam pembelajaran tidak akan sia-sia. Diharapkan agar siswa berlomba-lomba memperbaiki, meningkatkan dan mempertahankan sikap dan perilaku serta mengasah keterampilannya agar mendapat nilai yang baik.

Pada pembelajaran selanjutnya di siklus II, sudah berjalan sangat baik. Terlihat dari aktivitas guru pada siklus II pertemuan 1 sebesar $89 \%$ dengan kualifikasi sangat baik dan meningkat menjadi 94\% dengan kualifikasi sangat baik pada pertemuan 2. Rata-rata aktivitas guru pada siklus II sebesar 92\% dengan kualifikasi sangat baik. Sementara aktivitas siswa pada siklus II mencapai $81 \%$ dengan kualifikasi baik pada pertemuan 1 dan meningkat pada pertemuan 2 mencapai $86 \%$ dengan kualifikasi baik. Rata-rata aktivitas siswa pada siklus II sebesar $84 \%$ dengan kualifikasi baik. Peningkatan aktivitas guru dari pertemuan 1 ke pertemuan 2 sebesar 5\%. Sedangkan peningkatan aktivitas siswa dari pertemuan 1 ke pertemuan 2 sebesar $5 \%$.

Peningkatan aktivitas guru pada siklus II dikarenakan guru melaksanakan pembelajaran sesuai dengan perencanaan dan guru sudah dapat mengelola kelas serta mengatur waktu dengan baik. Temuan hasil aktivitas siswa pada siklus II pertemuan 1 dan pertemuan 2 menunjukkan bahwa siswa lebih aktif dalam kegiatan belajar mengajar dan kegiatan berdiskusi kelompok. Hal ini menunjukkan bahwa siswa sudah memahami dan terbiasa dengan langkahlangkah pembelajaran Numbered Heads Together yang mengutamakan kerja kelompok. Siswa sudah dapat bekerjasama dengan kelompok, mampu berinteraksi dengan siswa lainnya, mampu berpikir bersama dengan anggota kelompok, dan siswa mulai berani dalam mengemukakan pendapat dan menanggapi jawaban dari kelompok lain walaupun belum menyeluruh. Sejalan dengan pernyataan Nur (dalam Absari, 2016: 83) bahwa tujuan model Numbered Heads Together, adanya keterlibatan total semua siswa dan meningkatkan tanggungjawab individual dalam diskusi kelompok.

\section{Peningkatan Hasil Belajar PKn dengan Menggunakan Model Numbered Heads Together di Kelas V}

Nilai rata-rata hasil belajar siswa adalah 71 pada pertemuan 1 siklus I. Kemudian meningkat lagi menjadi 77 pada pertemuan 2 siklus I. Pada siklus II pertemuan 1, nilai rata-rata hasil belajar siswa 81 dan pada pertemuan 2 nilai ratarata hasil belajar siswa meningkat menjadi 84. Pada siklus I pertemuan 1 diketahui 6 siswa tuntas belajar dengan persentase $50 \%$, sedangkan pada pertemuan 2 di siklus I diketahui sebanyak 8 siswa dinyatakan tuntas belajar dengan persentase $67 \%$. Kemudian, pada siklus II pertemuan 1 diketahui 10 siswa dinyatakan tuntas

501 BRILIANT: Jurnal Riset dan Konseptual Volume 2 Nomor 4, November 2017 
belajar dengan persentase $83 \%$, dan pada pertemuan 2 sebanyak 11 siswa tuntas belajar dengan persentase $92 \%$.

Pada siklus I lebih tampak peningkatan hasil belajar siswa dibanding pada tahap pratindakan. Di siklus I digunakan penilaian tiga ranah yaitu sikap, keterampilan, dan pengetahuan. Siklus I pertemuan 1 diperoleh persentase nilai proses yang berasal dari nilai sikap dan nilai keterampilan adalah sebesar $73 \%$, dan rata-rata nilai pengetahuan sebesar 68 dengan persentase ketuntasan $42 \%$. Pada pertemuan 2 diperoleh persentase nilai proses (nilai sikap dan nilai keterampilan) adalah sebesar $76 \%$, dan rata-rata nilai pengetahuan siswa sebesar 76 dengan persentase ketunasan sebesar $75 \%$.

Pada siklus II, peneliti masih tetap menggunakan model Numbered Heads Together sebagai model yang diterapkan dalam pembelajaran. Hasil belajar siswa pada siklus II sudah lebih baik dari pada siklus I. Di siklus II digunakan penilaian tiga ranah yaitu sikap, keterampilan, dan pengetahuan. Siklus II pertemuan 1 diperoleh persentase nilai proses yang berasal dari nilai sikap dan nilai keterampilan adalah sebesar $82 \%$, dan rata-rata nilai pengetahuan sebesar 80 dengan persentase ketuntasan $75 \%$ dengan kualifikasi cukup. Pada pertemuan 2 diperoleh persentase nilai proses (nilai sikap dan nilai keterampilan) adalah sebesar $85 \%$, dan rata-rata nilai pengetahuan siswa sebesar 83 dengan persentase ketuntasan sebesar 83\% dengan kualifikasi baik. Ketuntasan klasikal pada siklus II telah mencapai ketuntasan belajar, yaitu 92\% sesuai dengan persentase minimal yang telah ditetapkan, yaitu $80 \%$. Maka dengan pencapaian tersebut pembelajaran tuntas dan tidak perlu melaksanakan siklus selanjutnya.

\section{KESIMPULAN}

Berdasarkan hasil pelaksanaan tindakan selama penelitian yang dilakuan, maka diperoleh kesimpulan bahwa Penerapan model pembelajaran Numbered Heads Together pada pembelajaran PKn dilaksanakan guru dengan baik dan sesuai dengan langkah-langkah pembelajaran Numbered Heads Together. Berdasarkan hasil pengamatan kemampuan guru dalam menggunakan model Numbered Heads Together pada pembelajaran PKn di siklus I adalah 78\% dengan kualifikasi baik, dan meningkat di siklus II, yaitu 92\% dengan kualifikasi sangat baik. Pembelajaran menjadi lebih aktif, hal ini dapat dilihat dari aktivitas siswa dalam proses pembelajaran yang mengalami peningkatan dari siklus I $76 \%$ dengan kualifikasi baik meningkat menjadi $84 \%$ dengan kualifikasi baik di siklus II. Hasil belajar siswa kelas V pada materi organisasi mengalami peningkatan. Hal ini dapat dilihat dari peningkatan hasil belajar siswa pada pembelajaran di siklus I dan siklus II. Pada tahap pratindakan, ketuntasan belajar klasikal sebesar 25\% dengan kualifikasi kurang sekali. Pada siklus I, ketuntasan belajar klasikal mengalami peningkatan sebesar $67 \%$ dengan kualifikasi cukup dan pada siklus II ketuntasan klasikal meningkat menjadi 92\% dengan kualifikasi sangat baik.

\section{SARAN}

Saran yang dapat diberikan adalah dengan adanya penelitian ini, Guru hendaknya dapat menerapkan dan mengembangkan model pembelajaran Numbered Heads Together pada pembelajaran PKn materi selanjutnya, agar siswa lebih mudah dalam memahami materi pembelajaran dan siswa lebih aktif dalam 
kegiatan belajar, sehingga dapat menciptakan suasana belajar yang menyenangkan dan dapat meningkatkan hasil belajar siswa.

\section{DAFTAR RUJUKAN}

Absari, R. P. 2016. Skripsi: Peningkatan Hasil Belajar IPS Materi Koperasi Melalui Model Numbered Heads Together di Kelas IV SDN Sumberdiren 01 Kabupaten Blitar. Skripsi tidak diterbitkan. Malang: FIP Universitas Negeri Malang.

Dimyati \& Mudjiono. 2006. Belajar dan Pembelajaran. Jakarta: Rineka Cipta.

Komalasari, K. 2010. Pembelajaran Kontekstual: Konsep dan Aplikasi. Bandung: Refika Aditama.

Lie, A. 2005. Cooperative Learning: Mempraktikkan Cooperative Learning di Ruang-Ruang Kelas. Jakarta: PT. Grasindo.

Rahayu, S. 2006. Model Pembelajaran Numbered Heads Together, (Online), (http//pelawiselatan.wordpress.com/2006/03/numbered-heads-togetherhtml), diakses pada 15 Januari 2016.

Sanjaya, W. 2008. Perencanaan dan Desain Sistem Pembelajaran. Bandung: Kencana Prenada Media Group.

Sudjana, N. 2009. Penilaian Hasil Proses Belajar Mengajar. Bandung: Remaja Rosdakarya.

Sugiyono. 2009. Metode Penelitian Pendidikan. Bandung: Alfabeta.

Trianto. 2007. Model-Model Pembelajaran Terpadu dalam Teori dan Praktik. Jakarta: Prestasi Pustaka. 